\title{
A Study of the Sayed Ashraf-Al-Din Gilani (Nasim-e-Shomal) Poems in the Light of Frankfurt School and Constitutional (Mashrooteh) Movement
}

\author{
Hamid Khanian \\ Department of Persian Language and Literature, Islamic Azad University, Ilam Branch, Iran
}

\begin{abstract}
Frankfurt school started its activity in 1928 by establishing an institute for social research. Some of the theorists of this school are Marcuse, Horkheimer, Adorno, Fromm and Benjamin Habermas. This school considered most of the thoughts and ideas of classical Marxism as incorrect and criticized them. Basically, in this school criticizing the poor condition of the school community has been an important component and art is considered as a medium to make the people aware of these problems. In Iran with the advent of the constitutional (Mashrooteh) movement, literature and art entered a new phase and the poets were committed to criticizing the disorders and social, political and cultural problems. They believed that the art with no benefit for the people's welfare and improvement of social and political conditions, and not used as a weapon against tyrants, is a worthless art. Thus, the authors in this study made an attempt to investigate these critical ideas in the works of one of the most prominent poets and critics of constitutional (Mashrooteh) era, sayed Ashraf-Al-Din Gilani known as Nasim-e-Shomal, and to determine the critical components in the poems of this renowned Iranian poet.
\end{abstract}

Index Terms-Frankfurt school, criticism, Mashrooteh, Sayed Ashraf-Al-Din Gilani (Nsim-e-Shomal)

\section{INTRODUCTION}

Frankfurt school was founded in 1928 and is associated with the institute for social research. It was transferred to New York in 1933 after Hitler exiled its members, but it was started again in Frankfurt in 1950. Marcuse, Horkheimer, Fromm and Benjamin are the theorists of this school and in the contemporary era Habermas and Peter Burger are the ones who have put the critical tradition of Frankfurt on the agenda (Taslimi, 2009, p. 151). In fact, there are four specific periods in the history of Frankfurt school:

1. The first period was 1923-1932, when the research carried out in the institute were completely diverse and were not a raw interpretation of Marxist ideology to be instilled in the critical theory. In this era, the founder of the institute, Karl Grunberg, was a social and economic historian who had a close association with the thoughts of Austrian Marxists and a noticeable part of the institute's works had mainly experimental nature.

2. The second era included the exile period in North America from 1933 to 1950 during which contrasting views (Hegelian critical theory) were firmly instilled as the principles of the institute's activities. The manager of the institute was Horkheimer in this era. In the policy of the institute, he devoted the philosophy of the superior map to himself instead of history and economy. This orientation was strengthened by the membership of Marcuse in 1922 and Adorno in 1938 following the little cooperation they had in 1931.

3. In the third era from the return of the institute to the Frankfurt school in 1950, the main viewpoints of critical theory were vividly formulated in a number of the works by member authors and scholars, leaving principal effects on their social views over time. Its scope of its influence was advanced later, especially after 1956 and the rise of the new left movement all over the Europe and the United States in which some of the members had remained. The great political and ideological effect of radical student movements reached its crescendo. Marcuse was introduced as the main representative of the Marxist critical theory. The impact of Frankfurt school gradually declined from early 1970, the period considered as the fourth period in the history of Frankfurt school. In fact, Frankfurt school came to an end with the death of Adorno in 1969 and Horkheimer in 1973. At last, Frankfurt school distanced from Marxism, which was once its source of inspiration (Monigh, et al., 2007). Frankfurt school has considered many predictions and ideas of classical Marxism as incorrect. They believed the capitalist society would downfall due to excessive exploitation of the working class and the deep social class contradictions. But, Marcuse states that the ruling class prevented the advent of socialism and its downfall by enhancing the working class welfare (Marcuse, 1983, p. 13-14).

The main ideas of the Frankfurt school are manifested in the critical theory. From this point of view, an idea should be committed and revealing because a kind of wide domination of vice on virtue and self-alienation on freedom is created (Marcuse, 1983). Critical theory is a kind of non-criminalist view which is mainly concerned with entire 
emancipation from oppression and repression as well as a commitment to freedom, prosperity and intellectual discipline in the society. The critical theory is against positivism. The works of four main characters, Marcuse, Horkheimer, Adorno and Fromm, constitute the core of the critical theory.

From the viewpoint of Horkheimer, et al., this theory is a precise explanation and rejection of colonialism and domination of false ideas and beliefs, an explanation that stresses exploitation system (Ahmadi, 2010).

According to this school, an original art is one that rejects and criticizes the present situation. In this theory, aesthetics in humanities and social sciences is not sufficient to explain the current situation, but the present situation should be taken into account. Therefore, social and human phenomena should be analyzed critically and the intellectuals have to take a critical position towards the society, a position aiming at informing the individuals to create changes in the present situation (Pour Alashti \& Abbasi, 2001, p. 2). Thus, the purpose of art is conflicting the present condition and showing dissatisfaction and aggression (Marcuse, 1971, p. 95).

One of the most important events in Iran during the past century was constitutional revolution (Mashrooteh). During this time, Iranians together with intellectuals, some of whom were poets and writers, had partly become familiar with the ideas of the Europeans. Literature entered a new era then whose objectives and aspirations included awakening the citizens, stimulating national patriotic feelings, promoting personal and social freedom, eliminating superstitions and wrong beliefs, criticizing the disorders severely (Momeni, 1973, p. 3) and familiarizing the people with their right (Yahaghi, 2004, p. 21).

It can be argued that commitment to the people and social, political and cultural issues of the society is one of the characteristics presented in the poems by these poets. Commitment in art, which is mostly interpreted as social commitment, is an issue in the history of art, especially in the contemporary period. The idea of beauty for beauty or art for art has been considered a dissenting idea in art. It can also be stated that literature in the constitutional system of Iran and Frankfurt school in Europe is fundamentally against supporting the power and wealth in capitalism. They believe that literature and art should not be a precious tool for the ruler to control the mind and awareness of the people, but it should criticize the problems. In fact, the Iranian intellectuals in the age of constitution (Mashrooteh) and supporters of Frankfurt school in Europe regularly criticize the chaotic condition and believe that the artist should not give up against the pressure of the ruling class on the society. In the poems of Sayed Ashraf-Al-Din Gilani (Nasim-e-Shomal), this critical view against the chaotic condition of the society is evident. Thus, the critical viewpoints of this poet of constitution (Mashrooteh) era are discussed in his poems.

\section{A. Criticizing the Marxist's Economic Theory}

Marxism is an economic theory that specifically examines the capitalist theory stating how forces and relations act in capital production style. By analyzing this economic relationship, one of the most important concepts of Marxism is obtained, the concept of alienation. There are two aspects in the Marxism's concept of alienation. First, the work that produces added value is an alienated work (separated from the worker), the work which is done on the merchandise to become part of the capitalist's benefit, therefore it does not belong to the worker. Second, in addition to alienating the worker from his labor power, capitalism alienates the worker from himself. When the worker is forced to sell his labor power, he is changed into merchandise too, that is the goods that are sold in the market. Thus, the worker that is changed into goods is not a complete person philosophically because he has no choice in the selection of the work. A worker forced to live in the labor market as merchandise is separated from humanity. When someone sells his work it becomes alien to him and changed into merchandise that is separated and different from the worker, something that is distinct from the producer. Disagreement of the working class and their exploitation by capitalists create the political contradictions of capitalism that consequently causes conflict among workers, owners, labor and capital (Klages, 2009, p. 173-174).

Sayed Ashraf-Al-Din Gilani criticizes the Marx's theory. In his poem entitled: "the king's talk with the laboring subject" this Iranian critical poet criticizes the capitalist's exploitation of the workers and makes the workers aware of the capitalists' exploitation:

You the poor are considered a human?

Why have you become Mirza Ghashmasham*?

Yدou are not allowed into the rich?

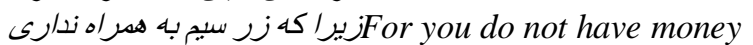

-In your kind hear you have nothing but sorrow

Why have you become so much old and frail?

Why have you become Mirza Ghashmasham?

(Nasim-e-Shomal, 1984, p. 276)

Then, Sayed Ashraf-Al-Din states that whoever owns the property and wealth owns status and glory and the subject is mean with no dignity.

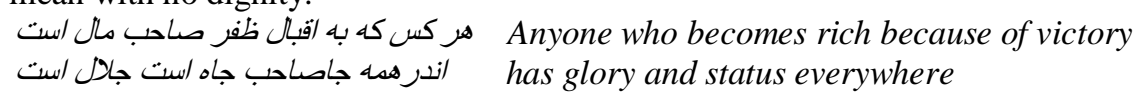

* Mirza Ghashmasham: a person who is poor and tries to show himself better than the what he is 
امروز يقين مال مسلط به كمال است

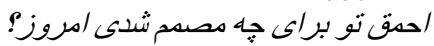

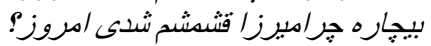

(ibid)

Later, in this poem the lord orders the subject to work for him, collect firewood in the forest and do whatever for his welfare. The poet has intended to inform the subjects of the exploitation imposed on them. He declares that he has even lost his hope in the constitution (Mashrooteh) to eliminate this injustice.

جork hard, you the poor worker

Go to forest and bring firewood, you the poor worker

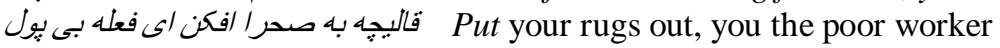

Then, a struggle happens between the king and the subject:

We are rich and you are poor

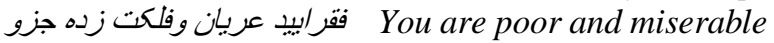

در نعدت ودولت هده محتاج مابيي

ه Although you have earned honor because of Mashrooteh

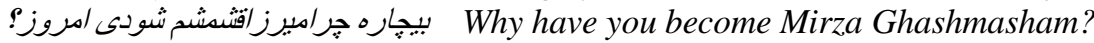

(ibid)

\section{B. Criticizing the Parliament}

Sayed Ashraf-Al-Din was an adroit poet and unique in terms of comic and irony. He was sort of the poets that appear every few centuries in the self-centered nations, captivate everyone by their eloquent speech, are naturally inspired by previous rulers and poets and arrange the others' innovative basics and renovate them with other words. This is an inborn art that not all people can possess.

From the beginning of the constitutionalist movement, poetry moved toward national and patriotic issues. The poets were more concerned with the people's affairs, integrity of the country, fighting against outsiders, supporting freedom, opposing the authoritarian ruling, etc. Using different figures of speech such as irony, they discussed this issue. With the advent of constitution (Mashrooteh), the literature of real irony appeared pointing at the society and public problems more than the people (Amin Pour, 2004, p. 136).

In the early constitutional era, the poets used poetry to express social, ethical and political criticisms along with irony and allegory (Aryan Pour, 1993, p. 120) and the parliament, as one of the most important political institutions, was involved in these poems. Sayed Ashraf-Al-Din Gilani is one of the prominent poets in the constitutional era that has criticized the parliament.

When the poet finds the parliament unable of establishing justice and improving the life of the people, he compares it to a broken carriage, scabbed dog, lame donkey and an addict that has no value and efficiency:

This broken carriage is not deserved riding

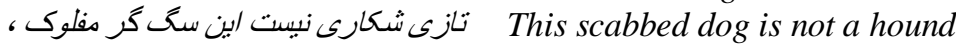

This black lame donkey is not cheatable

This addicted opponent is not a strong hero

(Nasim-e-Shomal, 1984, p. 381)

Afterwards, the poet hopelessly compares it with an infertile land and states that people have been waiting for good changes in their life for nine years, but the oppressed people have obtained nothing but sorrow and sadness from the parliament.

It is about nine years people have parliament

هo They are also connected to the heaven of justice

اندر /ين بهارستان كعبه /مان دارند

I see that the people are secured

The oppressed people have nothing but sorrow

There is no salvation in this ship of light

(ibid, p. 381)

Sayed Ashraf-Al-Din strongly criticizes the performance of the representatives of the parliament and the unsubstantiated promises they make to the people:

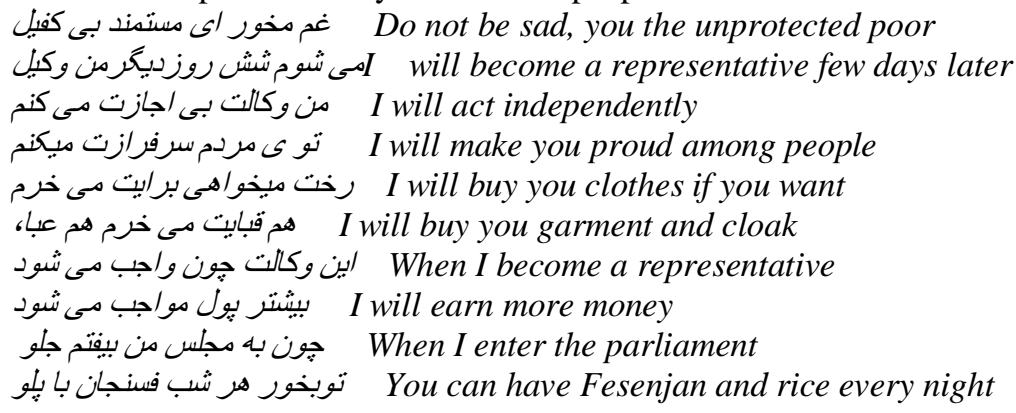


(ibid, p. 563)

Sayed Ashraf-Al-Din expects the representatives to make an attempt to establish justice and eradicate oppression. He declares that when the representatives of the parliament do their job properly the people will have no problems and Iran will prosper.

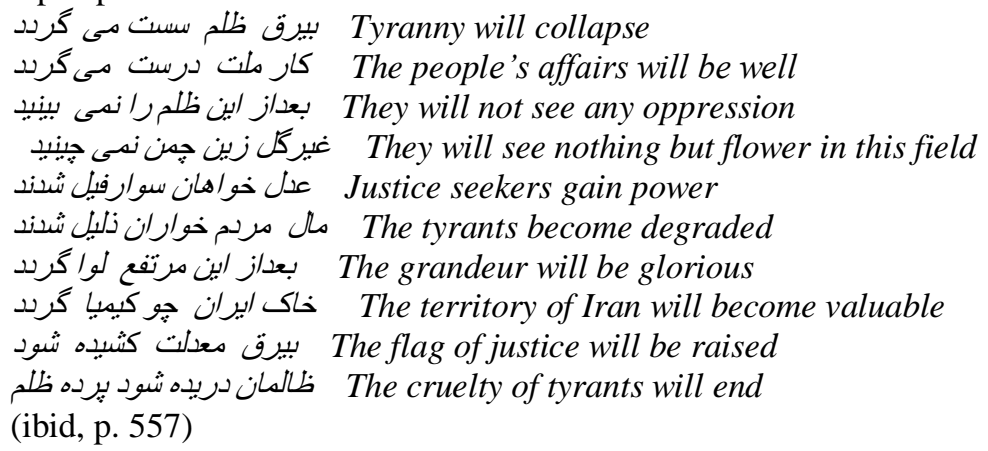

\section{Criticizing the People's Economic Poverty}

Inefficiency of the Qajar kings, disgraceful anti-national contracts, imprudence in the nation's economic affairs, indifference of the authorities toward the living conditions of the people and business owners and absence of social security system had grave effects on the economic status of the people, the people who suffered hunger, famine, unemployment, cold, oppression and inflation (Varasteh far, et al., 2010).

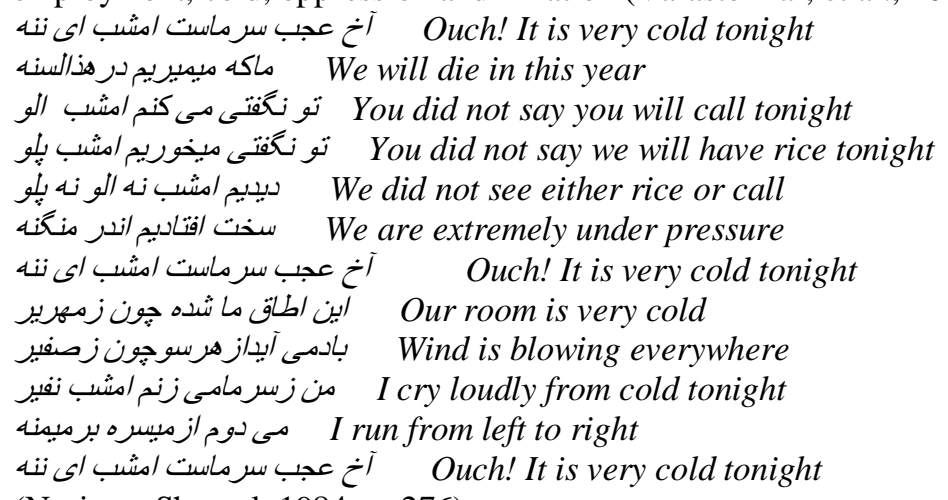

(Nasim-e-Shomal, 1984, p: 276)

As it is indicated, the theme of poverty and social class differences are presented in the poems of Sayed Ashraf-AlDin to illustrate this gap:

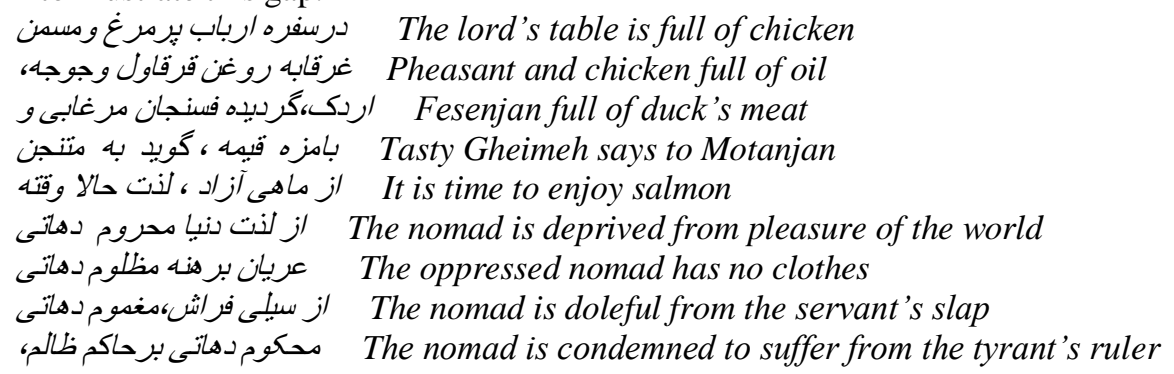

The concept of food (Fesenjan, Mosama, Chelo, Gheimeh, etc) is mentioned 131 times and there is certain logic behind this striking frequency. Inflation and lack of the basics have deprived people of many things and the poet, who belongs to the people, is quite familiar with their problems and wishes. While talking about the common structures in the poems of Mashrooteh, Ajoodani states that in the poems of Ashraf, in addition to his religious style, he has used the names of many foods to create such combinations as spirit of apple, spirits of Fallodeh, ice cream and Halva. To my opinion, such combinations, apart from their ironic and even religious nature of Ashraf's work, indicate poverty in the life of this friendliest poet of the time. As written in one of the most eloquent and effective affidavits, biographies written in his name, (Varasteh far, et al., 2010): most of the days he had kebab and broth ...... if we visited unexpected, he had broth or kebab ready. He also mentioned the name of various foods in his poems and you could not find any poem in which the word Fesenjan was not mentioned, but he never had Fesenjan. As he said:

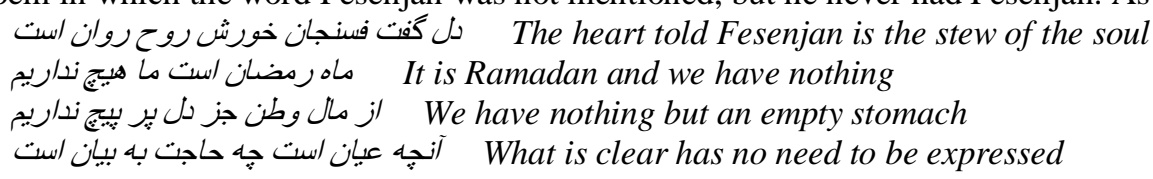

(Ajoodani, 2003, p. 195) 
The status and name of the jobs are mentioned in different parts of the collection (39 times). On the one hand, the jobs of the poor laborers that are being oppressed and on the other hand, the unfair merchants and frequently the representatives of the parliament (citing their opportunism and profit-seeking) illustrate the employment status of that time:

All the businesses prospered

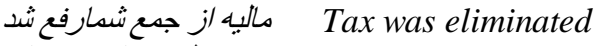

The state's torment was prevented

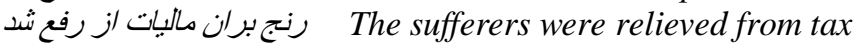

(Nasim Shomal, 1984, p. 110)

And about merchants:

Although the businesses are not flourishing

ولى جماعت تجار بارشان بار است

(ibid, 429)

The inflation, unemployment and recession following the economic crisis in 1905, war between Russia and Japan and consequently Russian revolution, severely influenced the economic status of the people so that in the first threemonth in 1905 the price of sugar and wheat rose by 33\% and 90\%, respectively in Tehran, Tabriz, Rasht and Mashad. As Sayed Ashraf-Al-Din describes the situation:
The world is very cruel
The Mohammad's religion is not promising
Business, industry and world are not good
The soil under is better than the soil on the top
Everybody complains about unemployment
Everybody is full of pain and sorrow

Of course, Ashraf uncovers the corruption:

Should I say manly and bravely or not

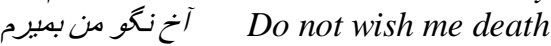

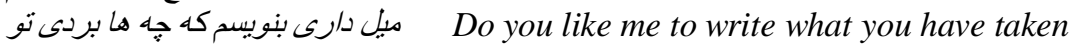

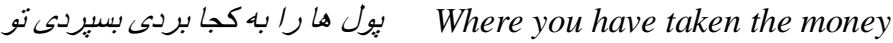

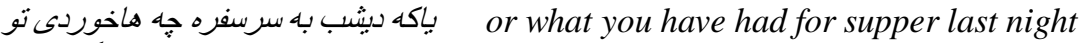

Should I tell about the wine and winery or not

آخ نكو من بهيرم

(Nasim-e-Shomal, p. 285)

And to become the representative of the parliament:

I I rubbed the people of all their properties

I Io not care about lawful and unlawful

جوشب شد فسنجان من حاضر است

The food is ready in my home

For my advocacy, a lot of money

فرستادم بيش موكول ها: Was given to me by my clients

(ibid, p. 471)

Although, during the Mozafaredin Shah reign, some amazing liberal policies such as opening travel to other countries, appointing Malkam to Iran's embassy in Rome, establishing trade and educational associations as well as emergence of liberalistic newspapers like Hablolmatin and Parvaresh that were published in Cairo and Calcutta were implemented, the economic condition was still chaotic and anti-national. For instance, traders were forced to pay more tariffs and land taxes were taken from the previous owners. Increasing land tax, reducing the pension of the clergies and controlling the endowments were other policies that caused public economic dissatisfaction (Varasteh Far, et al. 2010).

\section{Criticizing Constitution}

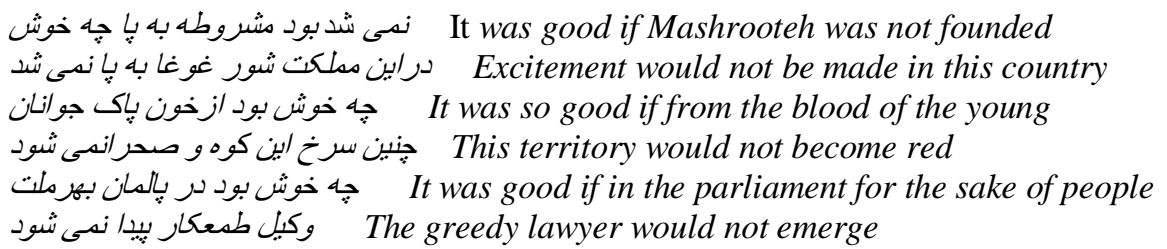

Or elsewhere, he strongly criticizes the constitution for not being employed to provide welfare and justice in the society.

كيفيت مشروطه ايران به كجارفت

As if it disappeared on delivery

كفتندزمشروطه شود مدلكت آباد

Good for tyranny 


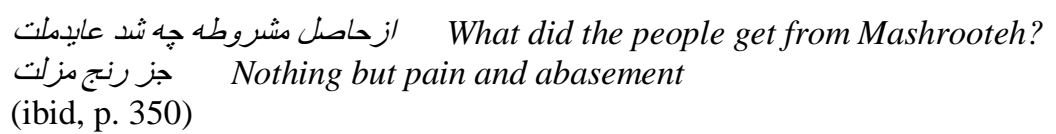

\section{E. Criticizing Tyranny and Dependency}

One of the most important critical poetic grounds of Sayed Ashraf-Al-Din Gilani is disagreement with puppet and colonial states. When Iran was under the dominance of Germany, England and Russia, in his poems, Sayed Ashraf-AlDin invited the people to unite and fight against colonialism, corruption and tyranny. This contemporary poet criticized.

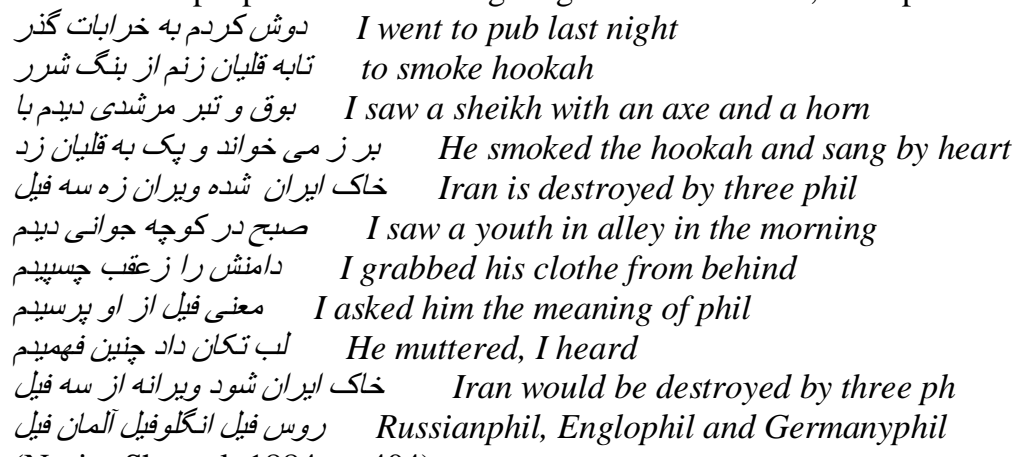

(Nasim Shomal, 1884, p. 404)

The poet blames colonization for creating problems for the people and destroying Iran. He informs people of the present situation and invites them to unification and solitary against tyranny and corruption.

Other examples of these critical poems are frequently found in the poems of Sayed Ashraf-Al-Din Gilani that invite the young to fight against colonialism and tyranny.

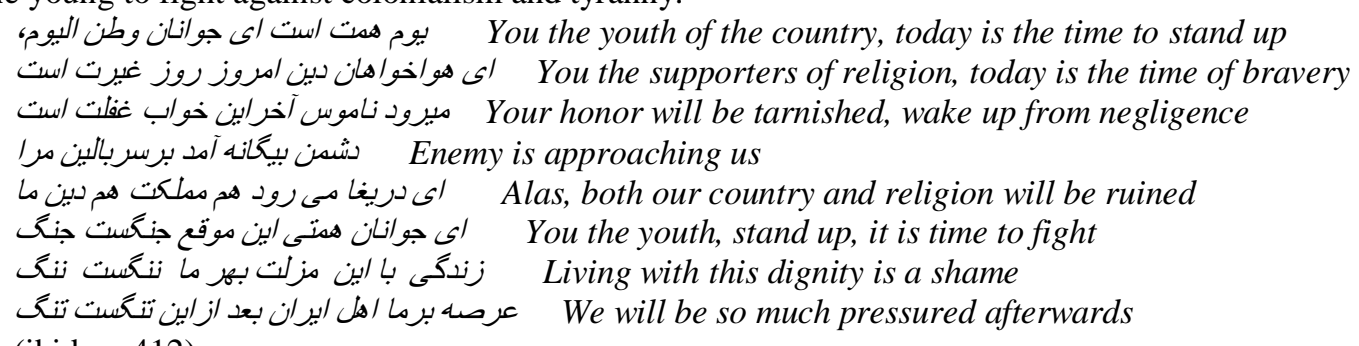

(ibid, p. 412)

\section{CONCLUSION}

Frankfurt school considers the ideas of classical Marxism as incorrect and criticizes them. This school had established criticism of the society's chaotic situation as its most important component. The main objective for the proponents of this school was to make people aware of the disorders, objection and criticism.

In Iran too, literature and art experienced a new period with the advent of the constitutional movement. The poets of this era took commitment to art into consideration as a certain and necessary principle. They believed that the art that has no benefit for the wellbeing of people and promotion of political and social condition and is not used as a weapon against tyrant is not artistic and beautiful. In fact, the Iranian poets in this era distance from the previous poets and employ literature at the service of the people's ideas in social and political issues.

In this period, literature is used to serve the people and criticizes the society's disorders. Thus, there is a similarity between Frankfurt literary school and constitutional (Mashrooteh) movement in literature and art in terms of criticism of the people's troubled condition.

By analyzing the poems of Sayed Ashraf-Al-Din Gilani (Nasim-e-Shomal), this fact can be figured out that the Iranian critical poet of Mashrooteh age by writing simple, eloquent and interesting poems, that were published in Nasim-e-Shomal, considered citing the events and criticizing the problems and addressing the condition of the working class, criticizing the inefficient parliament, etc. as commitment of literature in order to make improvements in the life of the people.

\section{REFERENCES}

[1] Ahmadi, B. (2010). Memories of darkness about three philosophers of Frankfurt school. Tehran Markaz publications, Tehran.

[2] Ajoodani, M. (2003). Mashrooteye Irani (Iranian constitutionalism). Akhtaran publications, Tehran.

[3] Amin Pour, Gh. (2004). Tradition and modernity in Iran's contemporary poetry, $1^{\text {st }}$ ed., Scientific and Cultural publications, Tehran.

[4] Gilani, S.A. (1996) Javdaneye Sayed Ashraf-Al-Din Gilani (Nasim-e-Shomal). Farzan Ketab publications, Tehran.

[5] Klages, M. (2009). Introduction to literary theories. (Translation) Jalal Sokhanvar, et al., Akhtaran publications, Tehran.

[6] Marcuse, H. (1971). One-dimensional man. (Translation) Mohsen Movayedifar, Amir Kabir publications, Tehran. 
[7] Momeni, B. (1973). Literature of constitution. $1^{\text {st }}$ ed., Gashaei publications, Tehran.

[8] Pour Alashti, H., Abbasi, H., Abbasi, R. (2001). The themes of poems of Farokhi Yazdi. Quarterly of language and literature. 17: 31-52.

[9] Taslimi, A. (2009). Literary criticism. Amad publications, Tehran.

[10] Varasteh Far, A. et al. (2010). The image of society in Nasime-e-Shomal. Pazhouhesh-Name-Farhang-o-Adab, 6: $372-394$.

[11] Yahaghi, MJ. (2004). Stream of moments (contemporary literature of Iran). $8^{\text {th }}$ ed., Jami publications, Tehran.

Hamid Khanian is an instructor at Islamic Azad University, Ilam Branch. He has been the member of several research societies. He has authored several books and papers. His recent published papers include some points about noun in Kalhori dialect, Iran Nameh journal, 2009, A Hura song in Kalhori, Iran and The Caucasus Journal, 2009, The rhetoric of Saadi in dealing with depression in Boostan and Golestan, Bahar Adab Journal, 2012. 